\title{
Grey water characterisation and pollutant loads in an urban slum
}

\author{
A. Y. Katukiza $\cdot$ M. Ronteltap - C. B. Niwagaba \\ F. Kansiime $\cdot$ P. N. L. Lens
}

Received: 12 July 2013/Revised: 15 October 2013/Accepted: 19 November 2013/Published online: 9 January 2014

(C) Islamic Azad University (IAU) 2013

\begin{abstract}
On-site sanitation provisions in urban slums rarely prioritise grey water management, yet it forms the largest fraction of wastewater. This study was carried out to characterise grey water and quantify its pollutant loads in Bwaise III (Uganda) and to provide data for grey water management in urban slums of developing countries. Samples were collected for analysis from ten representative households as well as from four tertiary drains and the main drainage channel for 7 months in two dry seasons. Grey water production was found to comprise $85 \%$ of the domestic water consumption. The chemical oxygen demand (COD) concentration in the grey water generated by laundry, in the kitchen and in the bathroom was $9,225 \pm 1,200 \mathrm{mg} \mathrm{L}^{-1}, 71,250 \pm 1,011 \mathrm{mg} \mathrm{L}^{-1}$ and $4,675 \pm 750 \mathrm{mg} \mathrm{L}^{-1}$, while the $\mathrm{BOD}_{5}$ (biochemical oxygen demand) to COD ratio was $0.24 \pm 0.05,0.33 \pm 0.08$ and $0.31 \pm 0.07$, respectively. The maximum concentration of Escherichia coli and total coliforms was $2.05 \times 10^{7}$ cfu $(100 \mathrm{~mL})^{-1}$ and $1.75 \times 10^{8} \mathrm{cfu}(100 \mathrm{~mL})^{-1}$, respectively, in grey water from the bathroom, while that of Salmonella spp. was $7.32 \times 10^{6} \mathrm{cfu}(100 \mathrm{~mL})^{-1}$ from laundry. Analysis of variance (ANOVA) showed a
\end{abstract}

A. Y. Katukiza $(\varangle) \cdot$ M. Ronteltap · P. N. L. Lens Department of Environmental Engineering and Water Technology, UNESCO-IHE Institute for Water Education, P.O. BOX 3015, 2601 DA Delft, The Netherlands e-mail: akatukiza@yahoo.com

A. Y. Katukiza · C. B. Niwagaba Department of Civil and Environmental Engineering, Makerere University, P.O. BOX 7062, Kampala, Uganda

F. Kansiime

Department of Environmental Management, College of Agricultural and Environmental Sciences, Makerere University, P.O. BOX 7062, Kampala, Uganda significant difference in the concentration of COD, total suspended solids (TSS), total organic carbon (TOC), dissolved organic carbon (DOC), total phosphorus (TP), sodium adsorption ratio (SAR), oil and grease, and Salmonella spp. in grey water from laundry, bathroom and kitchen $(p<0.05)$. The high loads of COD $\left(>500 \mathrm{~kg} \mathrm{day}^{-1}\right)$, TSS $\left(>200 \mathrm{~kg} \mathrm{day}^{-1}\right)$, nutrients $(8.3 \mathrm{~kg}$ TKN day ${ }^{-1}$ and $\left.1.4 \mathrm{~kg} \mathrm{TP} \mathrm{day}{ }^{-1}\right)$ and microorganisms $\left(10^{6}\right.$ to $\left.10^{9} \mathrm{cfu} \mathrm{c}^{-1} \mathrm{day}^{-1}\right)$ originating from grey water in Bwaise III show that grey water poses a threat to the environment and a risk to human health in urban slums. Therefore, there is a need to prioritise grey water treatment in urban slums of developing countries to achieve adequate sanitation.

Keywords Grey water - Environmental pollution · Sanitation $\cdot$ Slums

\section{Introduction}

The growth of slums in urban areas in developing countries causes sanitation challenges for the urban authorities. The main challenges are related to the collection as well as treatment of excreta, solid waste and wastewater for the protection of human health and the environment (Lüthi et al. 2009; Tilley et al. 2010; Thye et al. 2011; Katukiza et al. 2012). Faecal sludge management has traditionally been considered the main issue concerning improvement of sanitary conditions in urban slums because excreta are the source of many pathogens. In contrast, the grey water streams that account for the largest volumetric flux of wastewater generated in non-sewered urban slums have so far not been prioritised in sanitation provisions (Redwood 2008; Katukiza et al. 2012). In urban slums, grey water 
originates mainly from laundry, bathing and kitchen activities carried out at household level. The grey water return factor (proportion of water consumption that is converted to grey water) varies from 65 to $95 \%$ (Prathapar et al. 2005; Carden et al. 2007a; Jamrah et al. 2008; Abu Ghunmi et al. 2008, 2011). The quality and quantity of grey water are influenced by the high population density, unplanned low-cost housing units with limited accessibility, income level, cultural norms and type of cleaning detergents used (Eriksson et al. 2002; Morel and Diener 2006; Kariuki et al. 2012).

Grey water discharge results in both short-term and longterm effects on the environment and human health. Soil and ground water pollution and damage to crops are caused by high concentrations of boron, sodium or surfactants, some of which may not be biodegradable (Garland et al. 2000; Scott and Jones 2000; Abu-Zreig et al. 2003; Gross et al. 2005). In addition, nutrients in grey water may cause eutrophication whose occurrence depends on the self-purification capacity of the receiving environment (Harremoës 1998; Morel and Diener 2006). In particular, sodium tripolyphosphate is an ingredient of many detergents whose use has been associated with eutrophication (Köhler 2006). Furthermore, accumulation of heavy metals and micropollutants in the environment may cause toxicity through the food chain, distort the ecological balance (Schwarzenbach et al. 2006; Ternes and Joss 2006; Escher and Fenner 2011; Taghipour et al. 2013) and negatively affect humans and animals after long exposure time or after bioaccumulation and biomagnification (Snyder et al. 2003; Arjoon et al. 2013; González-Naranjo and Boltes 2013). Also pathogenic microorganisms in grey water may cause diseases that result in either morbidity or mortality depending on the severity and duration of the exposure (Eriksson et al. 2002; Ottoson and Stenström 2003; Birks and Hills 2007). These negative effects from grey water are likely to be more severe in slums where sanitation is inadequate.

Recent studies on grey water in peri-urban settlements in developing countries focused on its characteristics in relation to its re-use potential (Carden et al. 2007a; Kulabako et al. 2011; Kariuki et al. 2012) and its management options (Carden et al. 2007b; Armitage et al. 2009). However, there is limited information on the specific pollutant loads originating from the grey water stream in typical urban slums. Moreover, the variability of grey water quality along the tertiary drains from the generation point (households) to the open channels (surface water) under non-flooding conditions remains uninvestigated. The objectives of this study were, therefore, to characterise grey water and quantify its pollutant loads in a typical urban slum in sub-Saharan Africa and to provide data necessary to prioritise grey water management in urban slums of developing countries.

\section{Materials and methods}

Study area

This study was carried out in Bwaise III slum in Kampala city (Uganda) during the period of January-April 2010 and May-August 2012. It is a typical slum area located in a reclaimed wetland $\left(32^{\circ} 34^{\prime} \mathrm{E}\right.$ and $\left.0^{\circ} 21^{\prime} \mathrm{N}\right)$ and is drained by two major open storm water channels into which tertiary drains discharge grey water and storm water (Fig. 1). The area experiences two dry season periods from January to March and June to August. Even though there is an extensive coverage of piped water supply infrastructure in the study area, residents in the area do not necessarily access clean potable water because they cannot afford to pay. They resort to shallow ground water sources in the form of springs that are contaminated. The area is not sewered, and the majority of residents use on-site sanitation in the form of elevated pit latrines (Katukiza et al. 2010). There is no wastewater management system in place.

\section{Selection of households}

A total of ten households were selected after consultations with the local leaders and preliminary assessment of the current grey water practices in the study area. The following criteria were adopted: the equal representation for both tenants and landlords because of varying household size; the inclusion of households with and without children below 3 years because of contamination from bathing children and washing diapers; the willingness to cooperate and pour grey water types in separate containers; collection of samples for all grey water types during the study period; the use of only non-water borne sanitation facilities to guarantee a right estimation of grey water quantity; and the presence of a tertiary drain connected to the main drainage channel into which grey water from bathroom, kitchen and laundry activities is disposed.

\section{Selection of the tertiary drains}

In the study area, tertiary drains convey grey water from some households to storm water drains. Households located in places where there are no tertiary drains dispose grey water in the nearby open spaces. Two tertiary drains in the Katoogo zone and two in the St. Francis zone were monitored in this study. Figure 1 shows the location of the study area and the selected tertiary drains and households.

\section{Collection of grey water samples}

Grey water samples were collected and analysed during the periods of January-April 2010 and May-August 2012. 


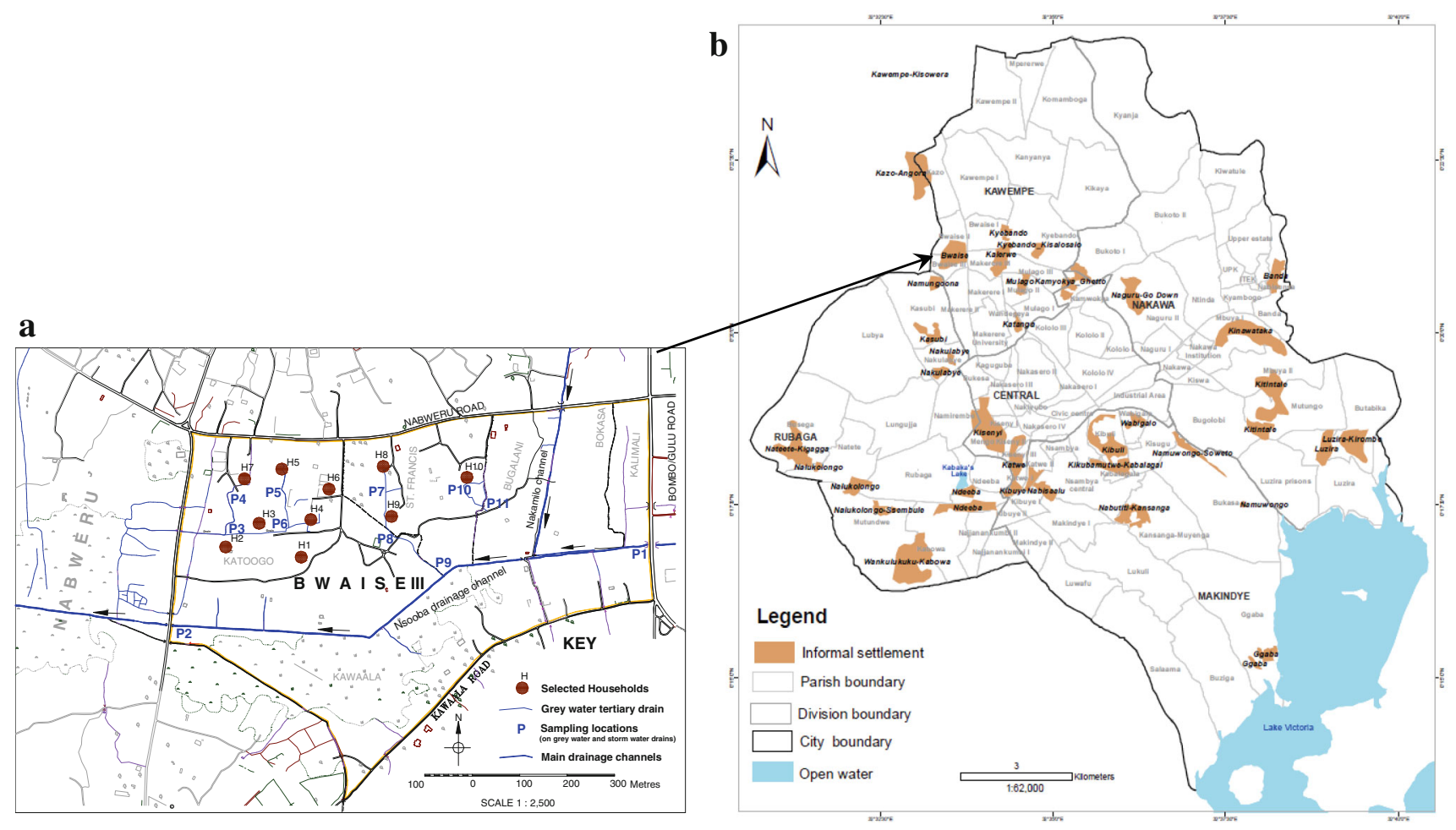

Fig. 1 a Location of the selected households and sampling locations on grey water drains and Nsooba drainage channel in Bwaise III and b Map of Kampala city in Uganda showing the location of Bwaise III

Samples for grey water from bathing, laundry and kitchen activities were collected in separate sterilised $200 \mathrm{~mL}$ sample bottles that were provided to households to separate their grey water types. Sampling was also done at locations $\mathrm{P} 1-\mathrm{P} 9$, which are along both the tertiary drains (conveying the grey water) and the Nsooba drainage channel (Fig. 1). Separate grey water samples were collected from households to determine the pollutant load from each source (laundry, bathroom and kitchen). In addition, sampling from tertiary drains and the main drainage channel was made in order to be able to investigate the variability of grey water quality along the tertiary drains from the generation point (households) to the open channels (surface water) under non-flooding conditions. The samples were stored in the dark at $+4{ }^{\circ} \mathrm{C}$ using ice blocks and transported to the Public Health and Environmental Engineering Laboratory at Makerere University (Uganda) for analysis within $1 \mathrm{~h}$ after sampling.

\section{Analytical techniques}

The $\mathrm{pH}$, temperature, dissolved oxygen (DO) and electrical conductivity (EC) were measured using portable Wissenschaftlich-Technische Werkstätten (WTW) meters pH 3310; Oxi 3310 and Cond 3310. The total organic carbon (TOC) and dissolved organic carbon (DOC) of non-filtered and filtered samples, respectively, were determined using a TOC-5000A (Shimadzu, Milton Keynes, UK). Samples for measurement of DOC were filtered through $0.45-\mu \mathrm{m}$ cellulose nitrate membrane filters. To eliminate leaching of DOC from the filter itself, a control procedure was followed. The filtration apparatus was rinsed with distilled water followed by leaching of DOC from the filters using $500 \mathrm{~mL}$ of distilled water to ensure the DOC of the leachate was $<0.1 \mathrm{mg} \mathrm{L}^{-1}$. The total suspended solids (TSS) concentration was measured following standard methods (APHA et al. 2005).

Chemical parameters $\left(\mathrm{COD}, \mathrm{BOD}_{5}, \mathrm{TP}\right.$, ortho-P, TKN, $\mathrm{NH}_{4}^{+}-\mathrm{N}$ and $\mathrm{NO}_{3}^{-}-\mathrm{N}$ ) were determined using standard methods (APHA et al. 2005). Chemical oxygen demand (COD) was determined using the closed reflux colorimetric method $(5220 \mathrm{C})$; Kjeldahl nitrogen was determined using the Kjeldahl method $\left(4500-\mathrm{N}_{\text {org }}\right)$; total phosphorus (TP) was determined using persulfate digestion followed by the ascorbic acid spectrophotometric method, while ortho-phosphorus was measured using the ascorbic acid spectrophotometric method (4500-P). $\mathrm{NH}_{4}^{+}-$ $\mathrm{N}$ was determined using the direct nesslerization method and $\mathrm{NO}_{3}^{-}-\mathrm{N}$ was determined using the colorimetric method with Nitraver 5 (Hach method 8039). Biochemical oxygen demand $\left(\mathrm{BOD}_{5}\right)$ was determined using the $\mathrm{HACH}$ BOD track (serial no. 26197-01; Loveland, Co 80539, 
USA). The oil and grease concentration was obtained by solid phase extraction using USEPA Method 1664A (USEPA 1999). The concentration of E. coli, total coliforms and Salmonella spp. was determined with Chromocult $^{\circledR}$ Coliform Agar media using the spread plate method (9215 C) (APHA et al. 2005).

Sodium was determined using a flame photometer, while calcium and magnesium were determined using atomic absorption spectrometry (type Perkin Elmer 2380). The sodium adsorption ratio (SAR) was determined using Eq (1).

$S A R=\frac{\left[\mathrm{Na}^{+}\right]}{\sqrt{\left(\left[\mathrm{Ca}^{2+}\right]+\left[\mathrm{Mg}^{2+}\right]\right)}}$,

where $\left[\mathrm{Na}^{+}\right],\left[\mathrm{Ca}^{2+}\right]$ and $\left[\mathrm{Mg}^{2+}\right]$ are concentrations in mmolL $^{-1}$ (Suarez 1981; Paliwal and Gandhi 1974; Ganjegunte and Vance 2006).

\section{Pollutant loads}

The specific pollutant loads from the discharge of untreated grey water into the environment were determined using the average concentration of various parameters in grey water generated at household level and the grey water production per capita per day. The following expression was used:

$P_{a v . c}=C_{n} x Q_{a v . c}$,

where $P_{a v . c}$ is the specific pollutant load produced per capita per day for parameter $n, C_{n}$ is the average concentration of parameter $n$ in grey water and $Q_{a v . c}$ is the average grey water production per capita per day, which was equal

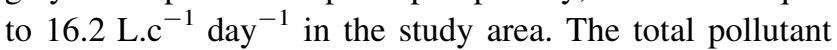
loads were determined as the product of the specific pollutant loads and the contributing population.

\section{Statistical analysis}

IBM SPSS statistics 20 software was used for statistical analysis. One-way analysis of variance (ANOVA) was used to determine the statistical (significant) differences in the concentration of various parameters in grey water from laundry, bathroom and kitchen activities at $95 \%$ confidence level. At $95 \%$ confidence interval, $p<0.05$ means that the values of a given parameter of grey water types are significantly different. Following ANOVAs, multiple comparisons using Tukey's test were done to ascertain that values were significantly higher or significantly lower or not significantly different based on the p-values while comparing values of the given parameters. The case of $p>0.05$ means that there is no significant difference in the parameter values. (Kansiime and van Bruggen 2001; Nsubuga et al. 2004; Mwiganga and Kansiime 2005).

\section{Results and discussion}

Quantity of grey water produced in Bwaise III

The average grey water production flow in the non-sewered Bwaise III parish was $243.8 \mathrm{~m}^{3}$ day $^{-1}$ based on the specific grey water production of $16 \pm 7 \mathrm{~L}^{-c^{-1}} \mathrm{day}^{-1}$ and a population size of 15,015 obtained from the local authorities. The sources of grey water were laundry, kitchen and bathroom activities. The return factor of grey water in Bwaise III was $85 \pm 7 \%$ (Table 1). The average water

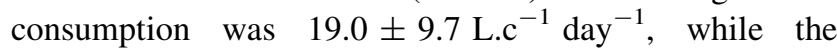
average household size was $7 \pm 3$ (Table 1). The sources of water in Bwaise III were piped water and spring water, with more than $80 \%$ of the water demand of the selected households met by spring water because it was free compared to tap water which costed US\$ 0.08 per $20 \mathrm{~L}$ jerry can in July 2012. The grey water contribution from laundry, bathroom and kitchen activities was 42,37 and $21 \%$, respectively.

The amount of grey water generated in Bwaise III was equivalent to $85 \pm 7 \%$ of the water consumption (Table 1). This represents a significant volume of waste water discharged into the environment. Although the specific water consumption of $19 \pm 9.7 \mathrm{~L}^{-1} \mathrm{day}^{-1}$ is below

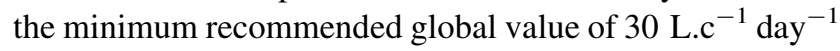
(WHO and UNICEF 2012) and the minimum national unit water consumption of $20 \mathrm{~L} . \mathrm{c}^{-1}$ day $^{-1}$, the high population density and high return factor lead to high volumetric fluxes of grey water discharge. The grey water return factor and water consumption in Bwaise III were within the reported range for peri-urban areas in sub-Saharan Africa of 75-95 \% and 15-30 L per capita per day, respectively (Alderlieste and Langeveld 2005; Morel and Diener 2006; Carden et al. 2007a).

Laundry and bathroom activities contributed the highest grey water volume generated in Bwaise III (Table 1). Kulabako et al. (2011) also found, based on household interviews, that the bulk of grey water in peri-urban Kampala was from laundry activities. In contrast, grey water studies in peri-urban areas of other parts of the world showed that 55-60\% of the grey water originated from either bathroom or showering (Busser 2006; Jamrah et al. 2008), while others found that washbasins and laundry machines each contributes about 16-33\% (Christova-Boal et al. 1996; Friedler 2004). The volume of grey water produced is thus dependent on the standard of living and sanitary infrastructure.

Physical and chemical characteristics of grey water in Bwaise III

The average $\mathrm{pH}$ of grey water from laundry, bathroom and kitchen activities in Bwaise III was $8.3 \pm 0.8,7.6 \pm 0.4$ 
Table 1 Household characteristics, water consumption and grey water production in Bwaise III

\begin{tabular}{|c|c|c|c|c|c|c|c|c|}
\hline \multirow[t]{2}{*}{ Household ID } & \multicolumn{3}{|c|}{ Household characteristics } & \multicolumn{3}{|c|}{ Quantity of water consumed } & \multicolumn{2}{|c|}{ Grey water produced } \\
\hline & Adults & $\begin{array}{l}\text { Children } \\
\text { ( }<3 \text { years of age })\end{array}$ & $\begin{array}{l}\text { Household } \\
\text { size }\end{array}$ & $\begin{array}{l}\text { Number of } \\
20-\mathrm{L} \text { jerry cans }\end{array}$ & 1/h day & $1 / p$ day & $\begin{array}{l}\text { Grey water } \\
(1 / \mathrm{h} \text { day })^{\mathrm{a}}\end{array}$ & $\begin{array}{l}\text { Return } \\
\text { factor }^{b}\end{array}$ \\
\hline H1 & 2 & 3 & 5 & 3 & 60 & 12 & 55 & 0.92 \\
\hline $\mathrm{H} 2$ & 4 & 4 & 8 & 6 & 120 & 15 & 95 & 0.79 \\
\hline $\mathrm{H} 3$ & 2 & 4 & 6 & 4 & 80 & 13 & 75 & 0.94 \\
\hline $\mathrm{H} 4$ & 7 & 0 & 7 & 5 & 100 & 14 & 85 & 0.85 \\
\hline H5 & 10 & 0 & 10 & 7 & 140 & 14 & 120 & 0.86 \\
\hline H6 & 10 & 4 & 14 & 10 & 200 & 14 & 160 & 0.80 \\
\hline $\mathrm{H} 7$ & 4 & 3 & 7 & 4 & 80 & 11 & 60 & 0.75 \\
\hline H8 & 2 & 4 & 6 & 8 & 160 & 27 & 120 & 0.75 \\
\hline H9 & 4 & 0 & 4 & 6 & 120 & 30 & 110 & 0.92 \\
\hline $\mathrm{H} 10$ & 3 & 0 & 3 & 6 & 120 & 40 & 110 & 0.92 \\
\hline Average & 5 & 2 & 7 & 6 & 118 & 19 & 99 & 0.85 \\
\hline Standard deviation & & & 3 & 2 & 42 & 9.7 & 32 & 0.07 \\
\hline
\end{tabular}

${ }^{a}$ Grey water from laundry, bathroom and kitchen activities in Bwaise III accounted for 42, 37 and $21 \%$, respectively

${ }^{\mathrm{b}}$ Return factor $=$ quantity of grey water produced per household per day/water consumption per household per day

a

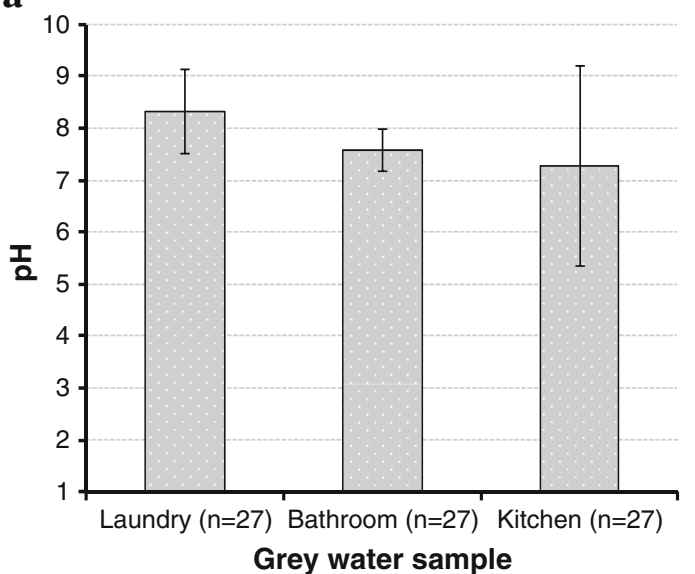

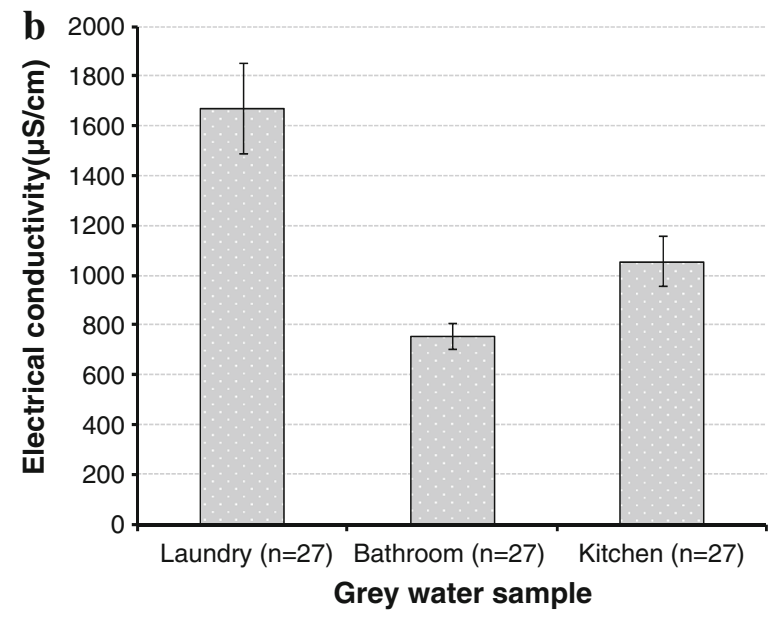

Fig. 2 a The $\mathrm{pH}$ and $\mathbf{b}$ electrical conductivity of grey water types generated in Bwaise III

and $7.3 \pm 1.9$, respectively (Fig. 2a). ANOVA indicated no significant difference in the $\mathrm{pH}$ of grey water from laundry, bathroom and kitchen activities $(p=0.127)$. The temperature of grey water from households and tertiary drains in Bwaise III varied from $19-29{ }^{\circ} \mathrm{C}$, while daily ambient temperature varied from 23 to $29^{\circ} \mathrm{C}$. The average EC of grey water from laundry, bathroom and kitchen activities was $1,671 \pm 936 \mu \mathrm{Sm} \mathrm{cm}^{-1}, 756 \pm 261 \mu \mathrm{Sm} \mathrm{cm}^{-1}$ and $1,057 \pm 518 \mu \mathrm{Sm} \mathrm{cm}^{-1}$, respectively (Fig. 2b). There was a significant difference in the EC of grey water from laundry, bathroom and kitchen activities $(p=0.01)$. Following ANOVA, multiple comparisons indicated that grey water from laundry had the highest EC, while the grey water from the bathroom has the lowest EC.

The average SAR of grey water from laundry, bathroom and kitchen activities in Bwaise III was $12 \pm 2,7 \pm 3$ and $8 \pm 3$, respectively (Fig. 3a). The SAR of grey water from laundry was significantly higher than the SAR of grey water generated in the bathroom and kitchen $(p=0.003)$. The concentration of oil and grease in grey water from laundry, kitchen and bathing activities was $2.5 \pm 1.2,27.5 \pm 3.7$ and $4.8 \pm 1.2 \mathrm{mg} \mathrm{L}^{-1}$, respectively (Fig. 3b). It was significantly higher in grey water from the kitchen than in grey water from either laundry or bathroom activities $(p=0.02)$. 

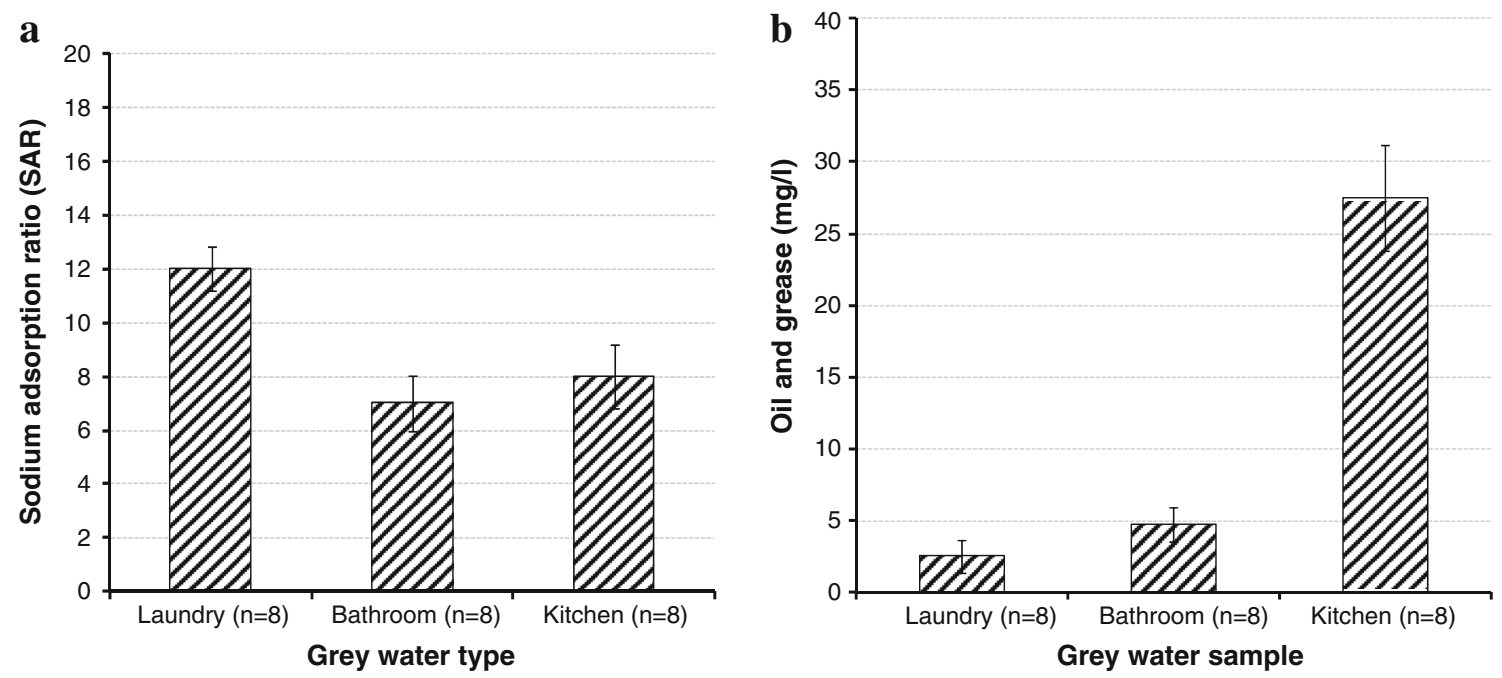

Fig. 3 a Sodium adsorption ratio (SAR) and $\mathbf{b}$ oil and grease concentration in grey water from Bwaise III
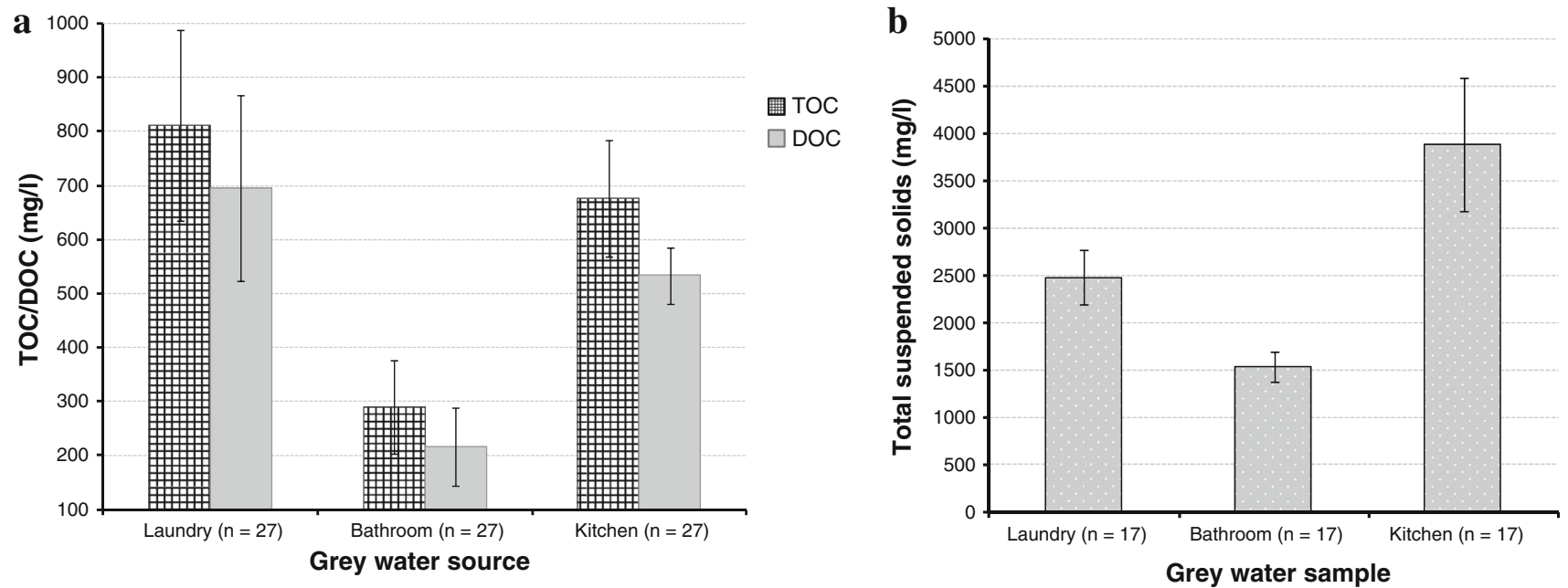

Fig. 4 a Total organic carbon (TOC) and DOC and b total suspended solids concentration in grey water from laundry, bathing and kitchen activities in Bwaise III

The average TOC and DOC values for grey water from laundry, kitchen and bathroom activities were $811 \pm 176$, $677 \pm 107,289 \pm 86$ and $695 \pm 171,216 \pm 73,533 \pm$ $52 \mathrm{mg} \mathrm{L}^{-1}$, respectively (Fig. 4a). ANOVA showed a significant difference in the concentration of TOC and DOC from laundry, bathroom and kitchen activities $(p=0.03 ; p=0.03)$. The average concentration of TSS in grey water from laundry, bathroom and kitchen activities was $2,478 \pm 1,301,1,532 \pm 633$ and $3,882 \pm 2,988 \mathrm{mg} \mathrm{L}^{-1}$, respectively (Fig. 4b). The concentration of TSS in kitchen grey water was significantly higher than that in laundry and bathroom grey water $(p=0.002)$.

Grey water from laundry activities accounted for the highest COD concentration $\left(9,225 \pm 1,200 \mathrm{mg} \mathrm{L}^{-1}\right)$, while grey water from the bathing accounted for the lowest
COD concentration $\left(4,675 \pm 170 \mathrm{mg} \mathrm{L}^{-1}\right) \quad$ (Fig. 5a). There was a significant difference in the concentration of COD from laundry, bathroom and kitchen activities in Bwaise III $(p=0.02)$. Grey water from laundry, bathroom and kitchen activities had a significantly higher COD than grey water from tertiary drains $(p=0.00, p=0.003$, $p=0.00$, respectively). The average $\mathrm{BOD}_{5}$ to COD ratio was $0.24 \pm 0.05,0.31 \pm 0.07$ and $0.33 \pm 0.08$ for grey water originating from laundry, bathroom and kitchen activities.

Grey water from laundry activities contained the highest TP concentration $\left(8.4 \pm 3.1 \mathrm{mg} \mathrm{L}^{-1}\right)$, while grey water from the bathroom activities had the lowest TP concentration $\left(4.3 \pm 1.9\right.$ in $\left.\mathrm{mg} \mathrm{L}^{-1}\right)$ (Fig. 5 b). There was a significant difference in the concentration of TP in grey 

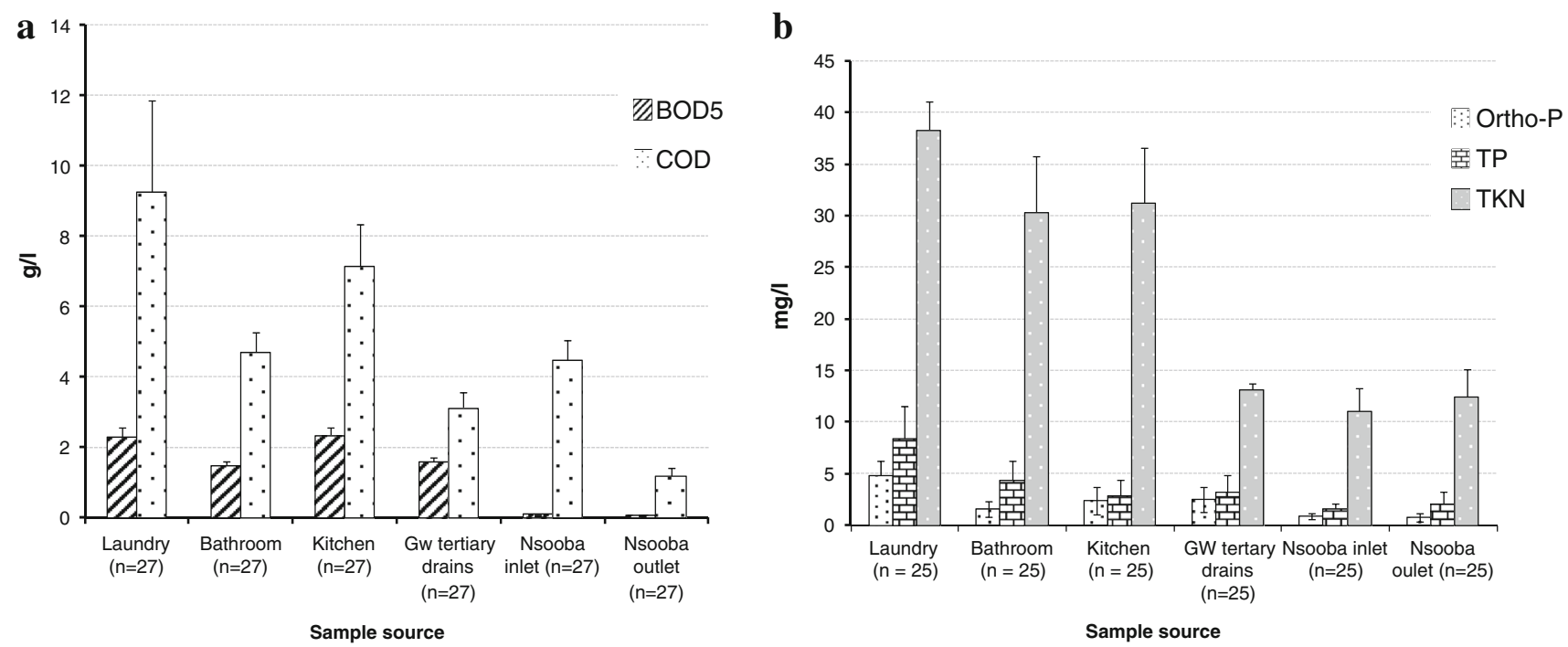

Fig. 5 a Comparison of the $\mathrm{COD}$ and $\mathrm{BOD}_{5}$ concentration and $\mathbf{b}$ nutrient levels of grey water from households and tertiary drains in Bwaise III, and surface water from the Nsooba channel

water from laundry, bathroom or kitchen activities $(p=0.003)$. The highest TKN concentration was $38.2 \pm 5.3 \mathrm{mg} \mathrm{L}^{-1}$ in grey water from laundry activities, while the lowest was $30.3 \pm 1.5 \mathrm{mg} \mathrm{L}^{-1}$ in grey water from kitchen activities (Fig. 5b). There was no significant difference in the concentration of $\mathrm{TKN}$ in grey water from laundry, bathroom and kitchen activities in Bwaise III $(p=0.105)$.

\section{Biodegradability of grey water}

The $\mathrm{BOD}_{5}$ to $\mathrm{COD}$ ratio of grey water from selected households in Bwaise III ranging from 0.24 to 0.34 and the $\mathrm{BOD}_{5}$ to TOC ratio of $1.2 \pm 0.7$ for mixed grey water show that it is not easily biodegradable. $\mathrm{A} \mathrm{BOD}_{5}$ to $\mathrm{COD}$ ratio of a wastewater stream close to or above 0.5 is an indication of its good biodegradability (Metcalf and Eddy 2003; Hernández et al. 2007; Li et al. 2009). The typical values for $\mathrm{BOD}_{5}$ to $\mathrm{COD}$ ratio of untreated municipal wastewater range from 0.3 to 0.8 , and the corresponding $\mathrm{BOD}_{5}$ to TOC ratio ranges from 1.2 to 2.0 (Crites and Tchobanoglous 1998; Metcalf and Eddy 2003). The $\mathrm{BOD}_{5}$ to COD ratio values obtained in this study were within the reported range of $0.21-0.35$ on grey water (Eriksson et al. 2002; Al-Jayyousi 2003; Jefferson et al. 2004).

The COD:N:P ratios of grey water from households (Table 2) indicate that grey water is deficient in nitrogen and phosphorus when compared with a value of 100:20:1 required for aerobic biological treatment (Jefferson et al. 2001; Metcalf and Eddy 2003). These data on grey water types from Bwaise III are important in the selection of grey
Table 2 Comparison of the COD:N:P ratio of grey water from Bwaise III and urban areas in other regions

\begin{tabular}{lll}
\hline Grey water source & COD:N:P & Reference \\
\hline Laundry & $100: 0.63: 0.09$ & This study \\
Bathroom & $100: 1.09: 0.09$ & \\
Kitchen & $100: 0.56: 0.04$ & \\
Laundry, bathroom & $100: 1.9: 0.07$ & \\
$\quad$ and kitchen & & \\
$\begin{array}{l}\text { Shower } \\
\text { Bathroom }\end{array}$ & $100: 2.91: 0.05$ & Jefferson et al. 2004 \\
$\begin{array}{l}\text { Handwash basin } \\
\text { Shower, bathroom, } \\
\quad \text { handwash basin }\end{array}$ & $100: 2.25: 0.06$ & \\
$\begin{array}{l}\text { Laundry, bathroom } \\
\text { and kitchen }\end{array}$ & $100: 1.94: 0.08$ & \\
$\begin{array}{l}\text { Laundry, bathroom } \\
\text { and kitchen }\end{array}$ & $100: 1.82: 0.76$ & Krishnan et al. 2008 \\
\hline & & \\
\hline
\end{tabular}

water treatment technologies for slums. The COD:N:P ratios were comparable to the values obtained for grey water from urban areas in other parts of the world (Table 2). This study did not include an inventory of household chemicals used in Bwaise III, which may further detail the poor biodegradability of grey water.

Microorganism concentration and loads in grey water

E.coli, Salmonella spp. and total coliforms were detected, respectively, in $67 \%, 61 \%$ and $100 \%$ of the 81 samples 
Fig. 6 Bacteriological quality of grey water from households and tertiary drains in Bwaise III

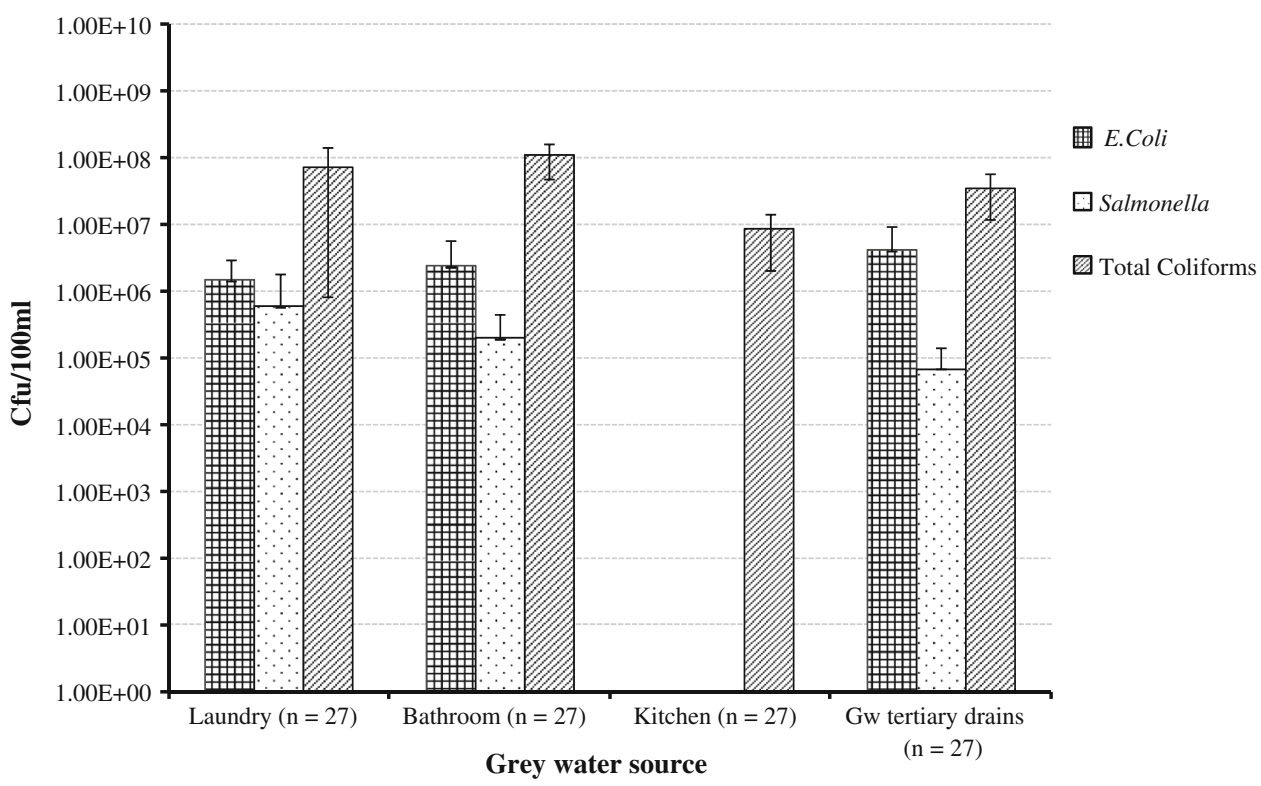

Table 3 Comparison of specific pollutant loads from grey water generated in Bwaise III and others parts of the world

\begin{tabular}{|c|c|c|c|c|c|}
\hline \multirow[t]{2}{*}{ Parameter } & \multirow[t]{2}{*}{ Unit } & \multicolumn{3}{|c|}{ Specific pollutant loads from grey water types in Bwaise III } & \multirow{2}{*}{$\begin{array}{l}\text { Reported specific } \\
\text { pollutant loads in grey } \\
\text { water (Busser 2006; } \\
\text { Friedler 2004; Morel } \\
\text { and Diener 2006) }\end{array}$} \\
\hline & & Laundry $(n=27)$ & Bathroom $(n=27)$ & Kitchen $(n=27)$ & \\
\hline TSS & g.c ${ }^{-1}$ day $^{-1}$ & $16.8 \pm 5.3$ & $9.2 \pm 3.3$ & $13.2 \pm 4.1$ & $10-30$ \\
\hline COD & g.c $\mathrm{c}^{-1}$ day $^{-1}$ & $62.6 \pm 15.5$ & $27.9 \pm 7.0$ & $24.2 \pm 6.1$ & $37-81$ \\
\hline BOD5 & g.c ${ }^{-1}$ day $^{-1}$ & $15.7 \pm 5.5$ & $13.4 \pm 3.6$ & $14.9 \pm 2.9$ & $20-50$ \\
\hline $\mathrm{TP}$ & g.c ${ }^{-1}$ day $^{-1}$ & $0.06 \pm 0.02$ & $0.03 \pm 0.01$ & $0.01 \pm 0.002$ & $0.2-6$ \\
\hline TKN & g.c $\mathrm{c}^{-1}$ day $^{-1}$ & $0.26 \pm 0.05$ & $0.19 \pm 0.07$ & $0.10 \pm 0.02$ & $0.6-3.1$ \\
\hline E.coli & cfu c $^{-1}$ day $^{-1}$ & $2.51 \times 10^{8}\left( \pm 1.7 \times 10^{7}\right)$ & $3.61 \times 10^{8}\left( \pm 4.5 \times 10^{7}\right)$ & - & - \\
\hline $\begin{array}{l}\text { Salmonella } \\
\text { spp. }\end{array}$ & cfu c $^{-1}$ day $^{-1}$ & $3.02 \times 10^{6}\left( \pm 2.9 \times 10^{6}\right)$ & $1.63 \times 10^{6}\left( \pm 1.3 \times 10^{6}\right)$ & - & - \\
\hline $\begin{array}{l}\text { Total } \\
\text { coliforms }\end{array}$ & cfu c $^{-1}$ day $^{-1}$ & $6.05 \times 10^{9}\left( \pm 1.96 \times 10^{9}\right)$ & $8.51 \times 10^{9}\left( \pm 1.1 \times 10^{9}\right)$ & $2.84 \times 10^{8}\left( \pm 1.21 \times 10^{8}\right)$ & $2.4 \times 10^{9}$ \\
\hline
\end{tabular}

${ }^{a}$ Compiled data based on mixed grey water studies in urban areas in USA, Asia and the middle East. No data from slums were available for comparison purposes

tested. The concentration of E.coli in grey water from laundry and bathroom activities in Bwaise III was $1.44 \times$ $10^{6}\left( \pm 1.46 \times 10^{6}\right) \quad \mathrm{cfu}(100 \mathrm{~mL})^{-1}$ and $2.35 \times 10^{6}$ $\left( \pm 3.34 \times 10^{6}\right) \mathrm{cfu}(100 \mathrm{~mL})^{-1}$. E.coli was not detected in grey water from kitchen activities (Fig. 6). The concentration of total coliforms in grey water from laundry, kitchen and bathroom activities was $7.15 \times 10^{7}( \pm 7.06 \times$ $\left.10^{7}\right) \mathrm{cfu}(100 \mathrm{~mL})^{-1}, \quad 5.87 \times 10^{7}\left( \pm 8.33 \times 10^{6}\right) \mathrm{cfu}$ $(100 \mathrm{~mL})^{-1}$ and $1.07 \times 10^{8}\left( \pm 5.87 \times 10^{7}\right) \mathrm{cfu}(100 \mathrm{~mL})^{-1}$, respectively. The concentration of Salmonella spp. in grey water from laundry and bathing in Bwaise III amounted to $5.74 \times 10^{5}\left( \pm 1.19 \times 10^{6}\right) \mathrm{cfu}(100 \mathrm{~mL})^{-1}$ and $1.94 \times 10^{5}\left( \pm 2.5 \times 10^{5}\right)$ cfu $(100 \mathrm{~mL})^{-1}$, and all samples from kitchen activities tested negative for Salmonella spp. ANOVA showed that there was a significant difference in the Salmonella spp. concentration $(p=0.03)$, but no significant difference in the E.coli concentration in grey water from laundry and bathroom activities in Bwaise III $(p=0.356)$. In addition, there was no significant difference in the concentration of total coliforms in grey water from laundry, bathroom or kitchen activities $(p=0.10)$.

The high concentrations of E. coli and Salmonella spp. in grey water from households and tertiary drains in Bwaise III pose a health risk to the slum dwellers 


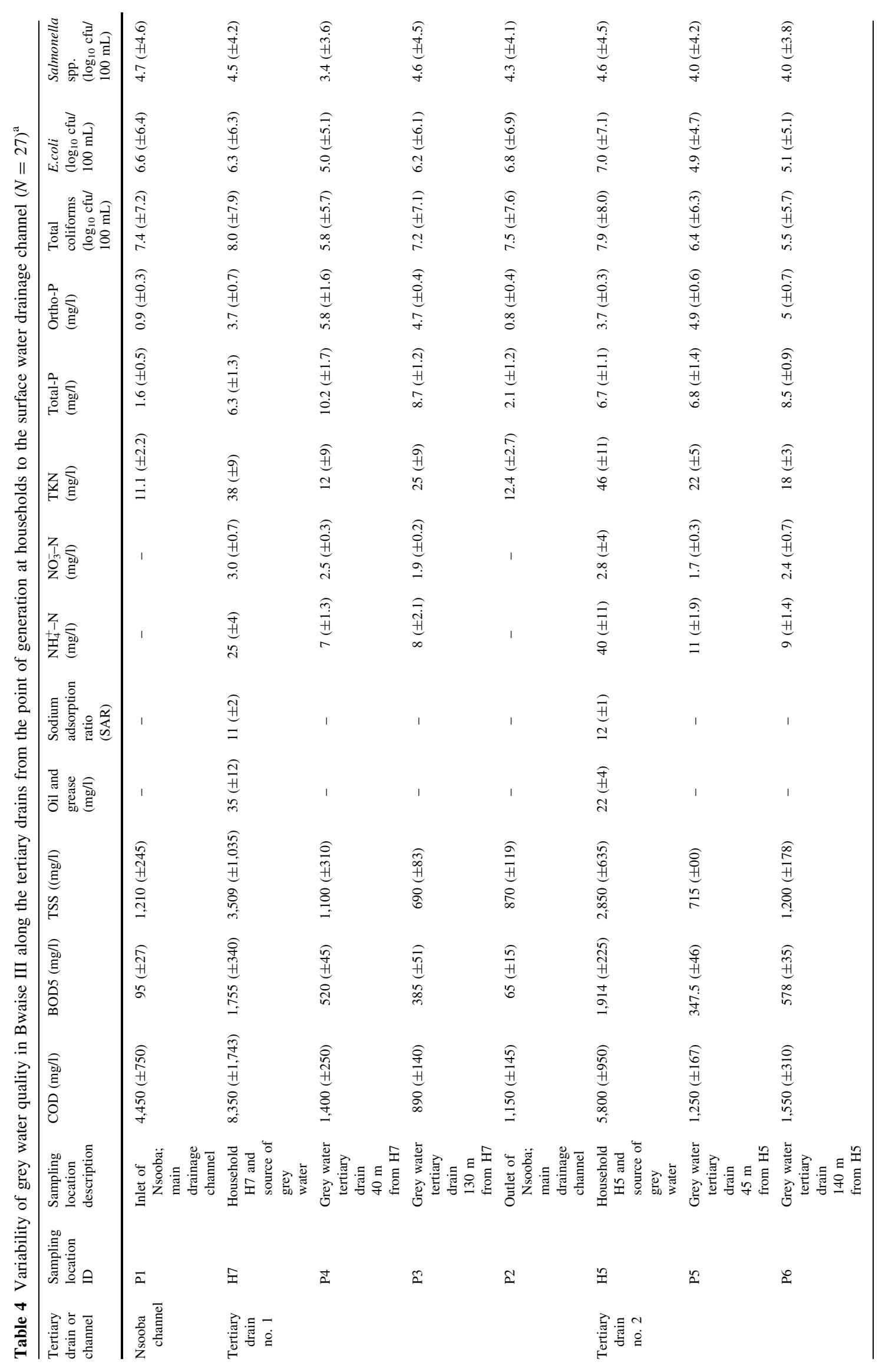




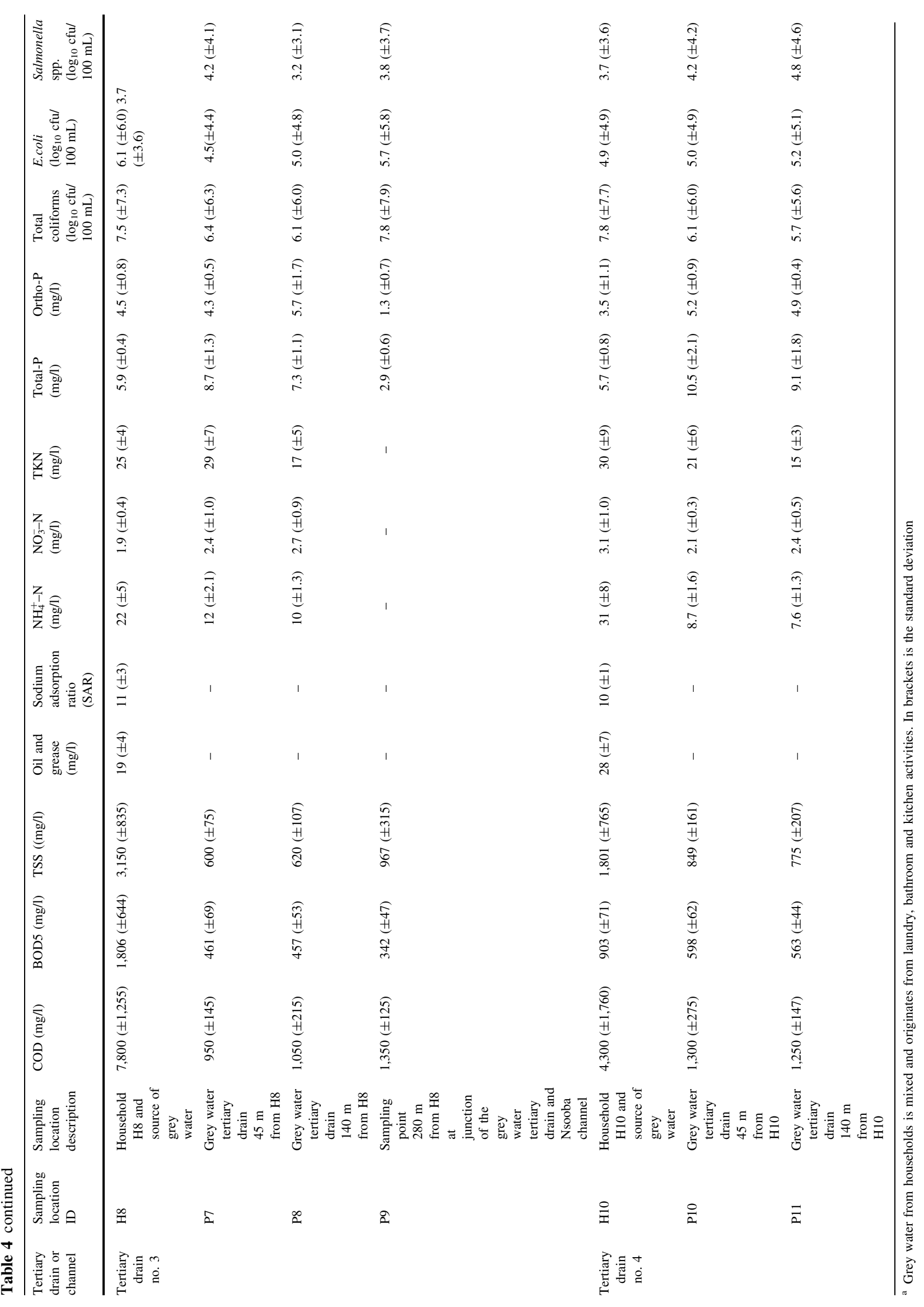


(Fig. 6). The $10^{4}-10^{8} \mathrm{cfu}(100 \mathrm{~mL})^{-1}$ concentration of microorganisms constitutes a health risk because about $8 \%$ of the determined concentrations of E.coli and Salmonella spp. are pathogenic (Haas et al. 1999; Westrell et al. 2004). Grey water generated in Bwaise III is therefore unfit for direct non-potable reuse, and its stagnation in the tertiary drains that have low slopes creates a potential source of exposure to waterborne pathogens. Despite the studies that have been carried out in periurban areas of sub-Saharan Africa (Carden et al. 2007a; Armitage et al. 2009; Kulabako et al. 2011; Kariuki et al. 2012), the data on microorganism loads in grey water from slums are very limited. The specific loads of microorganisms in grey water from laundry, bathroom and kitchen activities in Bwaise III were determined in this study (Table 3). Microorganism loads are useful in assessing the health effects during epidemiological studies and for controlling the source of pathogens to which slum dwellers are exposed.

The use of indicator organisms to determine the bacteriological quality of grey has limitations. Grey water in tertiary drains may be contaminated with many types of pathogens from different point and diffuse sources in the slum areas. The absence of indicator organisms in grey water samples may therefore not reflect the distribution of pathogens in grey water. For example, waterborne viruses were detected in grey water samples that tested negative for E.coli from locations along tertiary drains in the Bwaise III slum (Katukiza et al. 2013). There is thus a need for the use of other pathogen detection techniques like quantitative polymerase chain reaction. In addition, there is a need for a quantitative microbial risk assessment (QMRA) to determine the magnitude of the microbial risks to human health from exposure to grey water. Such a QMRA approach would also support the local authorities in making decisions on the measures to reduce the microbial risk and the disease burden in urban slums.

Specific pollutant loads originating from grey water

The specific pollutant loads discharged into the environment from grey water generated at household level were determined using the concentrations of the chemical and biological parameters, the average per capita water consumption per day, the return factor of $85 \%$ and the relative proportion of grey water fractions (Table 1). The specific pollutant loads of grey water from laundry, bathroom and kitchen activities were determined for TSS, COD, BOD 5 , TP, TKN and microorganisms (Table 3). Grey water from laundry in Bwaise III had the highest COD load, amounting to $149 \pm 37$ g.c $\mathrm{c}^{-1}$ day $^{-1}$, while grey water from the kitchen had the highest TSS load amounting to $63 \pm 21$ g.c ${ }^{-1}$ day $^{-1}$ (Table 3 ). In addition, the highest TP and TKN loads in grey water originated from laundry activities (Table 3). The E.coli load amounted to $5.98 \times 10^{8}\left( \pm 1.7 \times 10^{7}\right) \mathrm{cfu} \mathrm{c}^{-1}$ day $^{-1}$ and to $9.76 \times 10^{8}$ $\left( \pm 4.5 \times 10^{6}\right) \mathrm{cfu} \mathrm{c}^{-1}$ day $^{-1}$ in grey water from the bathroom and laundry, respectively, while the corresponding Salmonella spp. load was $4.41 \times 10^{6}\left( \pm 1.3 \times 10^{6}\right) \mathrm{cfuc}^{-1}$ day $^{-1}$ and $7.20 \times 10^{6}\left( \pm 5.9 \times 10^{6}\right) \mathrm{cfu} \mathrm{c}^{-1}$ day $^{-1}$. These values indicate that grey water from bathroom and laundry activities constitutes a high public health risk in the Bwaise III slum area. The values obtained in this study are comparable to specific grey water pollutant loads reported in the literature (Table 3).

Variation in grey water quality in tertiary drains

There was variation in the quality of grey water from the source at households to the sampling locations downstream along the tertiary drains. Table 4 shows that the concentration of COD in mixed grey water from households $\mathrm{H} 7$, $\mathrm{H} 5, \mathrm{H} 8, \mathrm{H} 10$ reduced by $70-86 \%$ in the tertiary drains, while the concentration of $\mathrm{BOD}_{5}$ reduced by $38-81 \%$ in the tertiary drains and by up to $96 \%$ in the main drainage channel of Bwaise III. A similar trend was found for the TSS.

The DO in the tertiary drains conveying grey water ranged from 0.03 to $1.87 \mathrm{mg} \mathrm{L}^{-1}$, which was comparable to the DO in the main open drainage channel of $<2 \mathrm{mg} \mathrm{L}^{-1}$ channel. The concentration of $\mathrm{NO}_{3}^{-}-\mathrm{N}$ varied from 1.4 to $3.5 \mathrm{mg} \mathrm{L}^{-1}$ for grey water samples from the tertiary drains and $<0.05 \mathrm{mg} \mathrm{L}^{-1}$ in the open drainage channel. These results show that hypoxic and anoxic conditions exist in the tertiary drains, while surface water in Nsooba drainage channel is hypoxic (DO concentration of $<1 \mathrm{mg} \mathrm{L}^{-1}$ ).

There was no clear trend exhibited by the concentration of nutrients (TP, Ortho-P, TKN) and microorganisms (E.coli, Salmonella spp. and total coliforms) from the point of generation downstream the tertiary drains. For example, the concentration of TP increased from $6.3 \pm 1.3$ to $10.2 \pm 1.7 \mathrm{mg} \mathrm{L}^{-1}$ and then decreased to $8.7 \pm 1.2$ $\mathrm{mg} \mathrm{L}^{-1}$ in tertiary drain 1 (Table 4 ). In tertiary drain 4 , the concentration of TP increased from $5.7 \pm 0.8$ to $10.5 \pm$ $2.1 \mathrm{mg} \mathrm{L}^{-1}$ and then decreased to $9.1 \pm 1.8 \mathrm{mg} \mathrm{L}^{-1}$. This variation was also found for Ortho- $\mathrm{P}, \mathrm{NO}_{3}^{-}-\mathrm{N}$ and $\mathrm{TKN}$ concentration in the monitored tertiary drains, and only $\mathrm{NH}_{4}^{+}-\mathrm{N}$ showed a consistent decrease downstream along the tertiary drains. In addition, the concentration of E.coli in tertiary drain 1 decreased from $6.3 \pm 6.3 \log _{10}$ cfu $(100 \mathrm{~mL})^{-1}$ to $5.0 \pm 5.1 \log _{10} \mathrm{cfu}(100 \mathrm{~mL})^{-1}$ and then increased to $6.2 \pm 6.1 \log _{10} \mathrm{cfu}(100 \mathrm{~mL})^{-1}$ (Table 4). This variation was observed in all monitored tertiary drains for both E.coli and Salmonella spp. concentrations. 
The concentration of COD, TSS and nutrients varied along the tertiary drains. There was a $70-86 \%$ reduction in the concentration of COD and TSS in grey water along the grey water tertiary drains from the generation sources at households to open channels (surface water). This was attributed to the sedimentation in the drains under dry weather flow conditions. Moreover, $61( \pm 6) \%$ of the measured total COD concentration was in particulate form (Fig. 5a). The concentration of nutrients varied along the tertiary drains without a clear trend (Table 4). This was probably due to the presence of other households downstream that discharge grey water in the same tertiary drains. Moreover, the concentration of microorganisms upstream and downstream along the tertiary drains was high (Table 4), which makes the stagnation of grey water in the tertiary drain in Bwaise III a major public health concern. Exposure to pathogens at points of grey water stagnation along the tertiary drains may be via involuntary ingestion of grey water especially by the children. It can also be through consumption of contaminated food since it is common in Bwaise III for families to prepare food near the drains because of limited space.

The potential environmental impacts of the grey water pollutant loads

The high COD load ( $>500 \mathrm{~kg} \mathrm{day}^{-1}$ ) of grey water generated in Bwaise III may induce hypoxic conditions in the main open surface water drainage channel. Grey water from laundry activities had the highest specific COD load (Table 3) because of re-using the same water for many cycles. This makes the contribution of laundry activities to the strength of grey water in Bwaise III considerable. In addition, the COD concentration of grey water generated in Bwaise III (Fig. 5) was higher than typical values ranging from 250 to $1,000 \mathrm{mg} \mathrm{L}^{-1}$ for untreated sewage (Metcalf and Eddy, 2003). Moreover, all the grey water types had a higher COD concentration $\left(>4,000 \mathrm{mg} \mathrm{L}^{-1}\right)$ than the discharge standard of $100 \mathrm{mg} \mathrm{L}^{-1}$ set by the National Environmental Management Authority (NEMA) in Uganda. Grey water generated in places such as slums with low

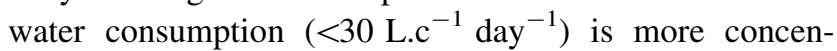
trated than grey water from affluent or higher income areas (Morel and Diener 2006). The low water consumption in Bwaise III thus contributes to the high COD concentration in grey water, while the high grey water return factor increased the COD load (Table 1).

The average nutrient loads discharged into the environment from grey water generated in Bwaise III were $8.2 \mathrm{~kg} \mathrm{day}^{-1}$ of TKN and $1.4 \mathrm{~kg} \mathrm{day}^{-1}$ of TP (Table 3). Macro-nutrients (nitrogen and phosphorous) are relevant for biological treatment processes and important for plant growth. However, they have a potential negative impact on the aquatic environment. The large quantities of grey water generated in Bwaise III contribute to significant loads of phosphorous and nitrogen that may cause eutrophication in the receiving water bodies downstream of the slum (Nyenje et al. 2010; Chuai et al. 2013). In addition, nutrient fluxes may also contaminate ground water through leaching in Bwaise III, where the water table is high $(<1 \mathrm{~m})$.

The concentration of oil and grease in grey water from Bwaise III is a major concern. Grey water especially from the kitchen had an oil and grease concentration exceeding the maximum discharge standard for wastewater effluents of $10 \mathrm{mg} \mathrm{L}^{-1}$ in Uganda (Fig. 3b). Therefore, current practice of grey water disposal in the open in Bwaise III without treatment may reduce soil aeration and also cause infiltration problems in Bwaise III (Mohawesh et al. 2013). Changes in the chemical composition of soil have been reported as a result of irrigation with effluents rich in petrochemical products (Sharma et al. 2012). Travis et al. (2008) also found that oil and grease cause soil water repellency and also form translucent films in the surface water, which interfere with aquatic life. These effects may occur in the receiving environment to which the Nsooba surface water channel discharges downstream of Bwaise III. The concentration of oil and grease obtained in this study was lower than the values reported in the literature (Christova-Boal et al. 1996; Carden et al. 2007a; Travis et al. 2008). This is attributed to the differences in kitchen activities and the living standards for affluent areas and also developed countries compared to urban slums. Concentrations of oil and grease ranging from 8 to $78 \mathrm{mg} \mathrm{L}^{-1}$ were observed in laundry grey water by Christova-Boal et al. (1996). The concentration of oil and grease in the grey water thus depends on household activities and eating habits.

The infiltration or re-use for irrigation of grey water may result in soil salinisation. The detrimental effects of sodium salinity and sodicity are determined based on the proportion of sodium $\left(\mathrm{Na}^{+}\right)$, calcium $\left(\mathrm{Ca}^{2+}\right)$ and magnesium $\left(\mathrm{Mg}^{2+}\right)$ in grey water or the values of SAR (Kariuki et al. 2012). The SAR values ranging from 4 to 15 obtained in this study are comparable to SAR values obtained for grey water in previous studies from peri-urban areas ranging from 2 to 12 (Kulabako et al. 2011; Kariuki et al. 2012). SAR values exceeding 50 may be obtained depending on the sodium salts used to produce detergents used at households (Patterson 2001; Friedler 2004). High SAR values $(>6)$ reduce soil aeration and permeability (Morel and Diener 2006). In addition, an increase in SAR as a result of long-term land application of grey water negatively affects soil properties and causes die off of some plant species (Gross et al. 2005). The high SAR (>6) is an indication that disposal of untreated grey water may cause 
long-term effects of salinity, low water infiltration rates and water clogging in urban slums if grey water management is prioritised.

\section{Conclusion}

Grey water from laundry, kitchen and bathroom activities in Bwaise III accounted for $85 \%$ of the domestic water consumption. The high concentration of disease causing microorganisms ranging from $10^{4}$ to $10^{8} \mathrm{cfu}(100 \mathrm{~mL})^{-1}$ poses a health risk and makes grey water not suitable for direct non-potable reuse although it contains nutrients. The high COD $\left(>4,000 \mathrm{mg} \mathrm{L}^{-1}\right)$ and poor bacteriological quality makes grey management an essential provision in slum sanitation. The low $\mathrm{BOD}_{5}$ to $\mathrm{COD}$ ratio of 0.24 to 0.34 indicates a low biodegradability of grey water. Pretreatment of grey water is essential to avoid clogging of the main treatment unit because of high TSS concentrations $\left(>1,500 \mathrm{mg} \mathrm{L}^{-1}\right)$ and the presence of oil and grease. The high organic load, accumulation of sodium, oil and grease, and microorganism loads from disposal of untreated grey water in Bwaise III pose a potential environmental and health risk. Therefore, there is need for research to quantify the impacts on the environment especially the ecosystem downstream urban slums and the public health risks from the grey water pollutant loads generated in urban slums in developing countries.

Acknowledgments This research was carried out as part of the research that was funded by the Netherlands Ministry of Development Cooperation (DGIS) through the UNESCO-IHE Partnership Research Fund. It was carried out in the framework of the research project 'Addressing the Sanitation Crisis in Unsewered Slum Areas of African Mega-cities' (SCUSA).

\section{References}

Abu Ghunmi L, Zeeman G, van Lier J, Fayyed M (2008) Quantitative and qualitative characteristics of grey water for reuse requirements and treatment alternatives: the case of Jordan. Water Sci Technol 58(7):1385-1396

Abu Ghunmi LA, Zeeman G, Fayyad M, Van Lier JB (2011) Grey water treatment systems: a review. Crit Rev Environ Sci Techno 41:657-698

Abu-Zreig M, Rudra RP, Dickinson WT (2003) Effect of application of surfactants on hydraulic properties of soils. Biosyst Eng 84:363-372

Alderlieste MC, Langeveld JG (2005) Wastewater planning in Djenné, Mali. A pilot project for the local infiltration of domestic wastewater. Water Sci Technol 51(2):57-64

Al-Jayyousi OR (2003) Greywater reuse: towards sustainable water management. Desalination 156(1):181-192

APHA, AWWA and WEF (2005) Standard Methods for the examination of water and wastewater. American Public Health Association, American Water Works Association and Water
Environment Federation publication, 21st edition. Washington DC, USA

Arjoon A, Olaniran AO, Pillay B (2013) Co-contamination of water with chlorinated hydrocarbons and heavy metals: challenges and current bioremediation strategies. Int J Environ Sci Technol 10(2):395-412

Armitage NP, Winter K, Spiegel A, Kruger E (2009) Communityfocused greywater management in two informal settlements in South Africa. Water Sci Technol 59(12):2341-2350

Birks R, Hills S (2007) Characterisation of indicator organisms and pathogens in domestic greywater for recycling. Environ Monit Assess 129:61-69

Busser S (2006) Studies on domestic wastewater flows in urban and peri-urban Hanoi. http://ir.library.osaka-u.ac.jp/dspace/ bitstream/11094/13204/1/arfyjsps2006_395.pdf; Accessed 7 Feb

Carden K, Armitage N, Winter K, Sichone O, Rivett U, Kahonde J (2007a) The use and disposal of grey water in the non-sewered areas of South Africa: Part 1-Quantifying the grey water generated and assessing its quality. Water SA 33(4):425-432

Carden K, Armitage N, Sichone O, Winter K (2007b) The use and disposal of grey water in the non-sewered areas of South Africa: Part 2-Grey water management options. Water SA 33(4):433-442

Christova-Boal D, Eden RE, McFarlane S (1996) An investigation into greywater reuse for urban residential properties. Desalination 106:391-397

Chuai X, Chen X, Yang L, Zeng J, Miao A, Zhao H (2013) Effects of climatic changes and anthropogenic activities on Lake Eutrophication in different ecoregions. Int $\mathrm{J}$ Environ Sci Techno 9(3):503-514

Crites RW, Tchobanoglous G (1998) Small and decentralized wastewater management systems. McGraw-Hill Companies, California

Eddy M (2003) Wastewater engineering: treatment and reuse, 4th edn. McGraw-Hill Companies, New York, NY

Eriksson E, Auffarth K, Henz M, Ledi A (2002) Characteristics of grey wastewater. Urban Water 4(1):85-104

Escher BI, Fenner K (2011) Recent advances in environmental risk assessment of transformation products. Environ Sci Technol 45:3835-3847

Friedler E (2004) Quality of individual domestic greywater streams and its implication for onsite treatment and reuse possibilities. Environ Technol 25(9):997-1008

Ganjegunte GK, Vance GF (2006) Deviations from the empirical sodium adsorption ratio (SAR) and exchangeable sodium percentage (ESP) relationship. Soil Sci 171(5):364-373

Garland JL, Levine LH, Yorio NC, Adams JL, Cook KL (2000) Graywater processing in recirculating hydroponic systems: phytotoxicity, surfactant degradation, and bacterial dynamics. Water Res 34:3075-3086

González-Naranjo V, Boltes K (2013) Toxicity of ibuprofen and perfluorooctanoic acid for risk assessment of mixtures in aquatic and terrestrial environments. Int J Environ Sci Technol. doi:10. 1007/s13762-013-0379-9

Gross A, Azulai N, Oron G, Ronen Z, Arnold M, Nejidat A (2005) Environmental impact and health risks associated with greywater irrigation: a case study. Water Sci Technol 52(8):161-169

Haas CN, Rose JB, Gerba CP (1999) Quantitative microbial risk assessment. Wiley, New York

Harremoës P (1998) Stochastic models for estimation of extreme pollution from urban runoff. Water Res 22(8):1017-1026

Hernández L, Zeeman G, Temmink H, Buisman C (2007) Characterization and biological treatment of greywater. Water Sci Technol 56(5):193-200

Jamrah A, Al-Futaisi A, Prathapar S, Harrasi AA (2008) Evaluating greywater reuse potential for sustainable water resources management in Oman. Environ Monit Assess 137(1-3):315-327 
Jefferson B, Burgess JE, Pichon A, Harkness J, Judd SJ (2001) Nutrient addition to enhance biological treatment of greywater. Water Res 35(11):2702-2710

Jefferson B, Palmer A, Jeffrey P, Stuetz R, Judd S (2004) Grey water characterisation and its impact on the selection and operation of technologies for urban reuse. Water Sci Technol 50(2):157-164

Kansiime F, van Bruggen JJA (2001) Distribution and retention of faecal coliforms in the Nakivubo wetland in Kampala, Uganda. Water Sci Technol 44(11-12):19-26

Kariuki FW, Ngángá VG, Kotut K (2012) Hydrochemical characteristics, plant nutrients and metals in household greywater and soils in Homa Bay Town. Open Environ Eng J 5:103-109

Katukiza AY, Ronteltap M, Niwagaba C, Kansiime F, Lens PNL (2010) Selection of sustainable sanitation technologies for urban slums-A case of Bwaise III in Kampala, Uganda. Sci Total Environ 409(1):52-62

Katukiza AY, Ronteltap M, Niwagaba CB, Foppen JWA, Kansiime F, Lens PNL (2012) Sustainable sanitation technology options for urban slums. Biotechnol Adv 30:964-978

Katukiza AY, Temanu H, Chung JW, Foppen JWA, Lens PNL (2013) Genomic copy concentrations of selected waterborne viruses in a slum environment in Kampala, Uganda. J Water Health 11(2): 358-369

Köhler J (2006) Detergent phosphates: an EU policy assessment. J Bus Chem 3(2): 15-30

Krishnan V, Ahmad D, Jeru JB (2008) Influence of COD:N: P ratio on dark greywater treatment using a sequencing batch reactor. J Chem Technol Biotechnol 83:756-762

Kulabako NR, Ssonko NKM, Kinobe J (2011) Greywater characteristics and reuse in tower gardens in Peri-Urban Areas- experiences of Kawaala, Kampala, Uganda. Open Environ Eng J 4:147-154

Li F, Wichmann K, Otterpohl R (2009) Review of technological approaches for grey water treatment and reuses. Sci Total Environ 407(11):3439-3449

Lüthi C, McConville J, Kvarnström E (2009) Community-based approaches for addressing the urban sanitation challenges. Int $\mathbf{J}$ Urban Sustain Dev 1(1):49-63

Mohawesh O, Mahmoud M, Janssen M, Lennartz B (2013) Effect of irrigation with olive mill wastewater on soil hydraulic and solute transport properties. Int J Environ Sci Technol. doi:10.1007/ s13762-013-0285-1

Morel A, Diener S. Greywater Management in Low and MiddleIncome Countries. Review of different treatment systems for households or neighbourhoods. http://www.eawag.ch/forschung/ sandec/publikationen/ewm/dl/GW_management.pdf; 2006. Accessed 03 Jan 2013

Mwiganga M, Kansiime F (2005) The impact of Mpererwe landfill in Kampala-Uganda, on the surrounding environment. Phys Chem Earth 30:744-750

Nsubuga FB, Kansiime F, Okot-Okumu J (2004) Pollution of protected springs in relation to high and low density settlements in Kampala-Uganda. Phys Chem Earth 29:11531159

Nyenje PM, Foppen JW, Uhlenbrook S, Kulabako R, Muwanga A (2010) Eutrophication and nutrient release in urban areas of subSaharan Africa: a review. Sci Total Environ 408(3):447-455

Ottoson J, Stenström TA (2003) Faecal contamination of grey water and associated microbial risks. Water Res 37(3):645-655
Paliwal KV, Gandhi AP (1974) Effect of salinity, SAR, Ca:Mg ratio in irrigation water, and soil texture on the predictability of exchangeable Sodium percentage. Soil Sci 122(2):85-90

Palmquist H, Hanaeus J (2005) Hazardous substances in separately collected grey-and blackwater from ordinary Swedish households. Sci Total Environ 348:151-163

Patterson RA (2001) Wastewater quality relationships with reuse options. Water Sci Technol 43(10):147-154

Prathapar SA, Jamrah A, Ahmed M, Al Adawi S, Al Sidairi S, Al Harassi A (2005) Overcoming constraints in treated greywater reuse in Oman. Desalination 186(1-3):177-186

Redwood M (2008) The application of pilot research on greywater in the Middle East North Africa region (MENA). Int J Environ Stud 65(1):109-117

Schwarzenbach RP, Escher BI, Fenner K, Hofstetter TB, Johnson CA, von Gunten U, Wehrli B (2006) The challenge of micropollutants in aquatic systems. Science 313:1072-1077

Scott MJ, Jones MN (2000) The biodegradation of surfactants in the environment. Biochim Biophys Acta Biomembr 1508(1-2): 235-251

Sharma NK, Bhardwaj S, Srivastava PK, Thanki YJ, Gadhia PK, Gadhia M (2012) Soil chemical changes resulting from irrigating with petrochemical effluents. Int $\mathbf{J}$ Environ Sci Technol 9(2):361-370

Snyder SA, Westerhoff P, Yoon Y, Sedlak DL (2003) Pharmaceuticals, personal care products, and endocrine disruptors in water: implications for the water industry. EnvironEng Sci 20(5):449-469

Suarez DL (1981) Relation between $\mathrm{pH}$ and sodium adsorption ratio (SAR) and an alternative method of estimating SAR of Soil or drainage waters. Soil Sci Soc Am J 45(3):469-475

Taghipour H, Mosaferi M, Armanfar F, Gaemmagami SJ (2013) Heavy metals pollution in the soils of suburban areas in big cities: a case study. Int J Environ Sci Technol 10(2):243-250

Ternes T, Joss A (2006) Human pharmaceuticals, hormones andfragrances: the challenge of micropollutants in urban water management. IWA publishing, London

Thye YP, Templeton MR, Ali M (2011) A critical review of technologies for pit latrine emptying in developing countries. Crit Rev Environ Sci Technol 41(20):1793-1819

Tilley E, Zurbrüg C, Lüthi C (2010) A flowstream approach for sustainable sanitation systems. In: van Vliet B, Spaargaren G, Oosterveer $\mathrm{P}$ (eds) Social perspectives on the sanitation challenge. Dordrecht, Springer, pp 69-86

Travis MJ, Weisbrod N, Gross A (2008) Accumulation of oil and grease in soils irrigated with greywater and their potential role in soil water repellency. Sci Total Environ 394(68):74

USEPA (2009) Method 1664 revision A: N-hexane extractable material (HEM; oil and grease) and silica gel treated N-hexane extractable material (SGT-HEM; non-polar material) by extraction and gravimetry. United States Environmental Protection Agency, Washington DC

Westrell T, Schönning C, Stenström TA, Ashbolt NJ (2004) QMRA (quantitative microbial risk assessment) and HACCP (hazard analysis and critical control points) for management of pathogens in wastewater and sewage sludge treatment and reuse. Water Sci Technol 50(2):23-30

WHO, UNICEF (2012) Progress on drinking water and sanitation. Joint Monitoring Programme for water supply and sanitation (JMP) 